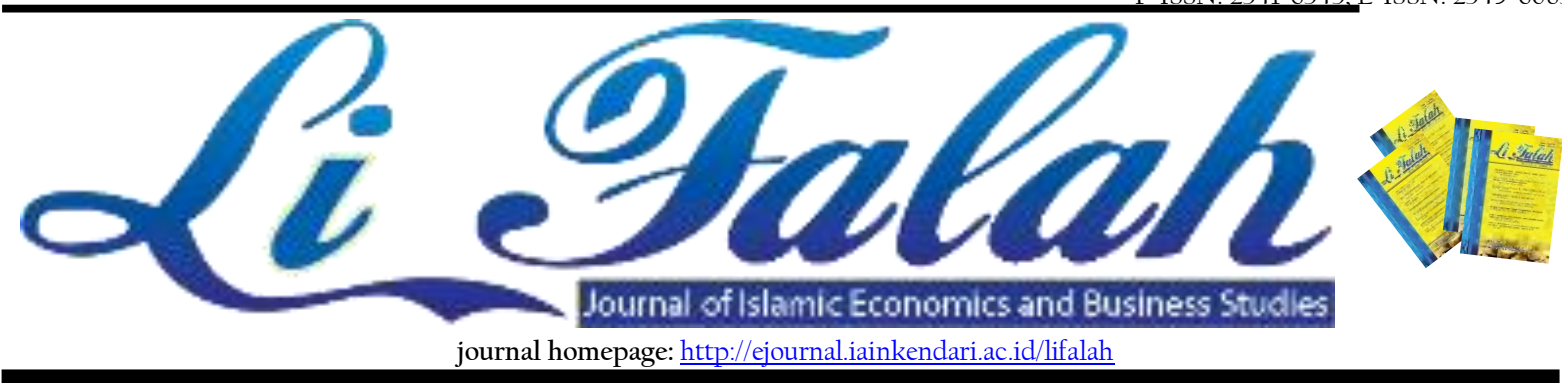

\title{
Overqualification as a Blunt Weapon on Productivity Improvement: Person-Job Fit Theory Integration
}

\author{
Ikhsan Maksum ${ }^{1}$, Nur Laili Fikriah², Agatha Mayasari ${ }^{3}$ \\ ${ }^{1,2}$ State Islamic University Maulana Malik Ibrahim Malang \\ ${ }^{2}$ University of Atma Jaya Yogyakarta \\ cmail: *1khsan.maksum@uin-malang.ac.id, ${ }^{2}$ nurlailifikriah31@uin-malang.ac.id, ${ }^{3}$ agatha.mayasari@uajy.ac.id
}

\begin{tabular}{|c|c|}
\hline ARTICLE INFO & A B S T R A C T \\
\hline $\begin{array}{l}\text { Article History: } \\
\text { Received } 17 \text { April } 2021 \\
1^{\text {st }} \text { Received in revised form } 19 \text { Mei } \\
2021 \\
2^{\text {st }} \text { Received in revised form } 10 \\
\text { June } 2021 \\
\text { Available online } 30 \text { Juni } 2020\end{array}$ & $\begin{array}{l}\text { Despite the growing number of studies that underlie the } \\
\text { influence between perceived overqualification (POQ) and } \\
\text { counterproductive behavior (PKP), there is still a gap in the } \\
\text { lack of research involving the role of affective mechanisms on } \\
\text { the effect of POQ on PKP. In this study, researchers focused } \\
\text { on the mediating role of job boredom (KTP) in the pathway of } \\
\text { influence of POQ on PKP. Using a sample of } 106 \text { employees } \\
\text { and lecturers at Islamic universities in Indonesia and } \\
\text { integrating the theory of person-job fit, the researchers found } \\
\text { that KTP fully mediates the effect of POQ on PKP. }\end{array}$ \\
\hline$\frac{\text { http://dx.doi.org/10.31332/lifal }}{\text { ah.v6i1.2781 }}$ & \\
\hline
\end{tabular}

\section{Introduction}

Along with the development of the labor market, the quality of the workforce has been increasing in recent decades. Improving the quality of the workforce is accompanied by an increase in a person's level of education, which is getting higher but not proportional to the availability of job opportunities. Job seekers need higher education to compete for jobs, even jobs that do not require a high level of education and ability. With the gap between the qualifications of a workforce and job qualifications, the term perceived overqualification (POQ) appears. The perception of overqualification is a phenomenon in the global labor market. Workers feel that they have qualifications (e.g., education, skills, and experience) higher than the job requirements (Erdogan, Bauer, Piero, \& Truxillo, 2011). 
High levels of unemployment and workers losing their jobs can force an individual to stay in a job below their working capacity (Liu, Luksyte, Zhou, Shi, \& Wang, 2014). Another fact that emerged is that overqualification does not only occur in developed countries (Maynard $\&$ Parfyonova, 2013) but is also found in many developing countries (Shen \& Kuhn, 2013). The phenomenon of overqualification in developed and developing countries arises due to the lack of compensation benefits for unemployment, for example, social security benefits. With this phenomenon, the discussion of overqualification has received attention from researchers, practitioners, and the mass media, making it enjoyable to study in different research contexts (Liu, Luksyte, Zhou, Shi, \& Wang, 2014).

Most previous studies on overqualification (POQ) perceptions have focused more on attitudes, health, and welfare (Liu \& Wang, 2012). However, overqualification can affect negative work behavior and counterproductive behavior (PKP) (Luksyte, Spitzmueller, \& Maynard, 2011). For example, workers who have overqualified perceptions of themselves tend to suffer more due to low psychological well-being and show lower organizational commitment. It can lead workers to negative work behaviors, such as counterproductive behavior (Kim, Park, Shon \& Lim, 2019). ). However, perceived overqualification (POQ) can provide mixed outcomes for workers and employers (Harari, Manapragada, \& Viswesvaran, 2017). However, the big question is whether POQ can directly affect PKP, or are there other factors involved in its influence? Considering the various outputs of the POQ.

Researchers include the mediating role of job boredom (KTP) to explain in detail the mechanism of why POQ affects PKP (Kim, Park, Shon \& Lim, 2019). The mediating effect of job boredom has received less attention for previous research. However, the theme of job boredom is essential to study because it can affect work behavior (e.g., counterproductive behavior). Moreover, overqualified workers often experience job boredom in various industries (Harju, Hakanen, \& Schaufeli, 2014). Industry or organization is an environment that can cause strong emotions for each organization member. Each individual in the organization has specific emotions that can impact certain behaviors, including job boredom.

Feelings of boredom that arise excessively can trigger the urge to run away from certain situations. Furthermore, a worker tends to engage in counterproductive behavior (PKP) (Kim, Park, Shon \& Lim, 2019) in a mechanism to reduce boredom. Thus, it can say that job boredom can play a crucial role in understanding the influence of counterproductive behavior. However, the mediating role to link overqualification (POQ) with counterproductive behavior (PKP) has not been studied empirically (Kim, Park, Shon \& Lim, 2019).

The researcher integrates the person-job (P-J) fit (Kristof-Brown \& Guay, 2011). P-J fit emphasizes the fit between a worker and the job he has. The P-J fit theory states that when workers feel that their work is not suitable for them, they can then give negative experiences such as job boredom. Inadequate levels of $\mathrm{P}-\mathrm{J}$ fit can be associated with low job satisfaction, greater desire to leave work, low overall performance, low extra-role behavior (OCB), and also counterproductive behavior (PKP) (Kim, Park, Shon \& Lim, 2019). Workers who perceive being overqualified and not suitable for a particular job can trigger negative feelings such as boredom at work, which, in turn, can lead to counterproductive behavior. 
Based on the theory of $\mathrm{P}-\mathrm{J}$ fit, the researcher aims to examine the effect of perceived overqualification (POQ) and counterproductive behavior (PKP) and the mediating role of job boredom (KTP) on the effect of perceived overqualification (POQ) on counterproductive behavior (PKP) (Kim, Park, Shon \& Lim, 2019; Liu, Luksyte, Zhou, Shi, \& Wang, 2014). As a contribution to science, the current study offers empirical evidence of KTP occurring on the job as a causal mechanism of the relationship between critical variables (e.g., perceived overqualification and counterproductive behavior). Researchers also tested the mediation model on the direct effect of POQ on PKP through KTP. With the current study results, researchers hope to offer knowledge about the mechanism of the mediating role of KTP on the influence between POQ and PKP, given the lack of literature discussing and testing these various variables (Kim, Park, Shon \& Lim, 2019).

\section{Literature Review}

\section{Perception of Overqualification as the basis for the Mismatch between Workers and their Jobs}

Consistent with previous research (Liu, Luksyte, Zhou, Shi, \& Wang, 2014; Maynard \& Parfyonova, 2013; Kim, Park, Shon \& Lim, 2019), researchers argue that person-job (P-J) fit is the most It is good to photograph the phenomenon of overqualification is a perception which states that a worker has excess qualifications which illustrate the mismatch between a worker and the qualifications required for the job. Specifically, workers who have excess qualifications make it possible to meet and even exceed the qualifications needed in completing the main tasks assigned by the organization (Liu, Luksyte, Zhou, Shi, \& Wang, 2014). This impact occurs when workers have excess qualifications and cannot practice specific skills. Therefore, they need challenges from work to develop their abilities. Furthermore, workers who cannot practice their skills and find challenges in a job can cause negative feelings such as lack of job satisfaction and increase counterproductive behavior (Luksyte, Spitzmueller, \& Maynard, 2011).

Previous literature reviews on the theory of P-J fit (Kristof-Brown \& Guay, 2011) stated that a worker's incompatibility with his job usually leads to adverse outcomes and vice versa; fit is a critical factor between workers and organizations to improve performance, attitudes, and positive behaviors. Related to work. In line with the theory of $\mathrm{P}-\mathrm{J}$ fit, the poor fit between workers and their jobs can trigger low job satisfaction, high desire to leave work, and performance in general (Kim, Park, Shon \& Lim, 2019), and also have an impact on poor psychological conditions (Liu, Luksyte, Zhou, Shi, \& Wang, 2014). Moreover, previous research has shown that an overqualified worker can trigger the desire to look for another job (Maynard \& Parfyonova, 2013) and deviant behaviors such as job boredom and counterproductive behavior (Luksyte, Spitzmueller, \& Maynard, 2011).

\section{Perception of Overqualification and Counterproductive Behavior}

Working in a job that does not match the job qualifications is one of the most frustrating experiences. A worker who has a perceived overqualification may increase the tendency to counterproductive behavior, which aims to relieve feelings of wasted valuable resources (e.g., time, energy, and knowledge) (Luksyte, Spitzmueller, \& Maynard, 2011). Specifically, based on the theory of $\mathrm{P}-\mathrm{J}$ fit, a person can respond to unfavorable situations in his work environment 
that cause not only feelings of frustration, but more broadly include negative emotions such as anger, dissatisfaction, hatred, and boredom (Harari, Manapragada, \& Viswesvaran, 2017), and the consequences for emotional reactions that stimulate PKP (Kim, Park, Shon \& Lim, 2019).

Integrating the theory of person-job fit, the researcher argues that POQ can positively affect PKP. Previous literature states that there are two types of PKP, namely PKP that harms the organization (e.g., criticizing organizational policies) and PKP that can harm individuals within the organization (e.g., speaking ill of colleagues) (Holtz \& Harold, 2013). The researcher understands that PKP caused by POQ can be aimed at one of the targets (e.g., organizations or individuals). The P $\mathrm{J}$ fit model states that a person's mismatch with his job can provide a bad experience for workers. A mismatch of worker qualifications with job requirements can trigger negative emotions (Harari, Manapragada, \& Viswesvaran, 2017). People who have excess qualifications (e.g., skills, abilities, knowledge, and experience) will feel angry with their organizations for not providing job challenges (Luksyte, Spitzmueller, \& Maynard, 2011) and can further trigger PKP:

Hypothesis 1: Perception of overqualification has a positive effect on counterproductive behavior.

\section{Perception of Overqualification and Job Boredom}

Building on the P-J fit theory and previous research, researchers understand that POQ can be integrated into the P-J fit model (Kim, Park, Shon \& Lim, 2019; Liu, Luksyte, Zhou, Shi, \& Wang, 2014). P-J fit relates to the compatibility or suitability between workers and their jobs. POQ is a perceived mismatch of worker qualifications (e.g., skills, abilities, knowledge, and experience) and job demands. When a worker feels unsuitable for his job, it can trigger negative experiences, such as job boredom (Kim, Park, Shon \& Lim, 2019). Work boredom can be interpreted as an unpleasant feeling and negative influence from the work environment and is characterized by low passion and dissatisfaction that comes from low stimulation in the work environment (Reijseger, Schaufeli, Peeters, Taris, van Beek, \& Ouweneel, 2013).

Following the definition presented by Reijseger, Schaufeli, Peeters, Taris, van Beek, \& Ouweneel (2013), KTP is a form of emotional reaction to a work environment that is less stimulating for a worker and subsequently causes a worker to feel that their abilities are underutilized. Well, or even they feel there is no match between their qualifications (e.g., skills, abilities, knowledge, and experience) and job requirements (Liu \& Wang, 2012). To support the argument that there is a relationship between POQ and KTP, the researcher includes previous research from Watt and Hargis (2010), which used a sample of workers in the health sector. The study results stated that there was a positive relationship between POQ and KTP. In addition, KTP can also affect jobs with low workloads and jobs that do not utilize skills (Kim, Park, Shon \& Lim, 2019). 


\section{Job Boredom and Counterproductive Behavior}

The current research is built and integrated with the theory of $\mathrm{P}-\mathrm{J}$ fit, which emphasizes more on the suitability and suitability of a worker with the work he is doing by focusing on the emergence of negative emotions (Luksyte, Spitzmueller, \& Maynard, 2011) by showing job boredom as part of an individual's assessment, and subsequently engage in counterproductive behavior (van Hooff \& van Hooft, 2014). PKP itself is defined as voluntary behavior that can harm other organizations and individuals (Holtz \& Harold, 2013). According to the P-J fit theory, which focuses on the suitability and suitability of workers' qualifications and job requirements, negative emotions arising from KTP can trigger an increase in PKP. To support this statement, Bruursema, Kessler, and Spector (2011) found that KTP positively influences PKP.

\section{Mediation Role of Job Boredom on the Effect of Perceived Overqualification on Counterproductive Work Behavior}

Job boredom is a negative emotion that plays a crucial role in understanding the influence of POQ and PKP. As evidence, the researcher uses supporting data from Liu, Luksyte, Zhou, Shi, \& Wang (2014), which found that overqualified workers tend to experience anger towards work environment situations and lead to PKP behavior. Furthermore, another study from Deng, Guan, Wu, Erdoan, Bauer, \& Yao (2018) states that when a worker experiences a perception of overqualification, they will feel less skilled interpersonally, feel less socially accepted, and these negative emotions can reduce work productivity. They. From the two previous research findings, the researcher hopes that POQ can be positively related to PKP through the mediating role of KTP.

KTP arises when an individual's skills are above average and job challenges are below average, so situations like this can lead to perceptions of overqualification (Liu \& W Wang, 2012). In addition, when a worker feels bored with their job, they often feel that they lack the knowledge, skills, and abilities used in carrying out a job. In other words, an overqualified worker believes that their job does not provide the variety they want and thus can engage in PKP (Kim, Park, Shon \& Lim, 2019).

Based on the P-J fit theory, the researcher argues that overqualified workers tend to do a cognitive analysis of their incompatibility with their work environment (Liu, Luksyte, Zhou, Shi, \& Wang, 2014). In addition, overqualified workers tend to experience adverse emotional reactions because their organization cannot meet their needs and challenges. These affective reactions include anger and hatred for situations and conditions that are not favoring workers (Gibson \& Callister, 2010). From the two types of affective reactions, it can say that there is poor compatibility between workers and their jobs. The research of van Hooff \& van Hooft (2014) states that KTP can mediate the effect of POQ on PKP. Liu and Wang (2012) support the findings, stating that VAW can be an emotional reaction to POQ and directly encourage maladaptive work behavior. Logically, the incompatibility felt by workers with their work can lead to a lack of stimulation at work, and then workers feel bored, so they tend to be involved in PKP. Research on POQ emphasizes that VAW plays a crucial role in explaining the mechanism of indirect influence of POQ on PKP (Kim, Park, Shon \& Lim, 2019): 
Hypothesis 2: Job boredom mediates the effect of perceived overqualification on counterproductive behavior

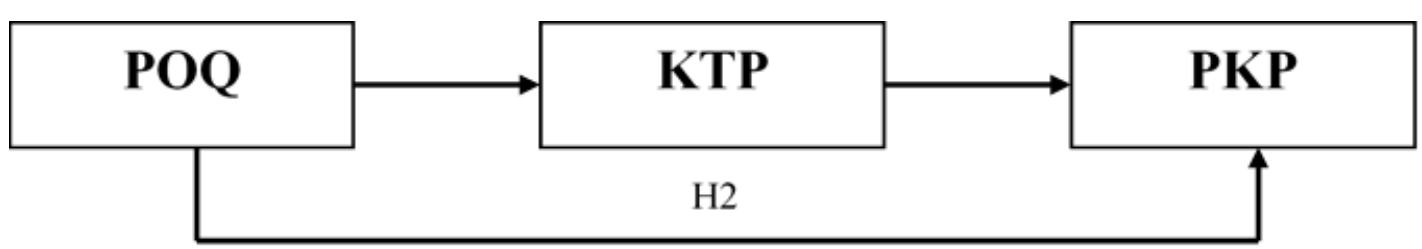

$\mathrm{H} 1$

Figure 1. Conceptual framework

\section{Research Method}

\section{Sample}

The research refers to the positivistic paradigm that emphasizes the causality mechanism between research variables and uses a deductive quantitative research approach (Maksum, Handoko, \& Fikriah, 2020). Collecting research data using cross-sectional by collecting data at a specific time using a questionnaire. The purpose of cross-sectional is to capture a picture of the phenomenon at a specific time and confirm the research hypothesis formulated in this study (Cooper \& Schindler, 2014).

Researchers recruited 106 respondents who worked full time. In recruiting activities, the researcher aims to collect information from respondents from various Islamic-based public and private universities and young people. Researchers set the criteria for workers working in Islamic-based public and private universities and young respondents because respondents with these criteria tend to experience perceptions of overqualification and are easier to engage in counterproductive behavior (Luksyte, Spitzmueller, \& Maynard, 2011). Research by Green \& Z hu (2010) shows support for the opinion of the researcher that the perception of overqualification tends to occur among workers who are still relatively young, for this reason, the researchers recruited young workers who work at various state and private Islamic Universities in several areas within the scope of Indonesia. Researchers set an age limit for respondents between 25 to 45 years (Luksyte, Spitzmueller, \& Maynard, 2011) who work in banking organizations and have at least one year of service.

\section{Measurement}

The researcher determined each measurement instrument used to measure the research variables using a five-point Likert scale starting with points 1 (strongly disagree) to 5 (strongly agree).

Perception of Overqualification - POQ. Researchers measure POQ using a 9-item measurement scale adopted from the Perceived Overqualification scale developed by Maynard, Joseph, \& Maynard (2006), which has been validated and has been used in previous research (Kim, Park, Shon \& Lim, 2019; Reijseger, Schaufeli, Peeters, Taris, van Beek, \& Ouweneel, 2013; 
Harari, Manapragada, \& Viswesvaran, 2017). Using a 5-point Likert scale (point 1, which means strongly disagree with pointing 5 , which means strongly agree), respondents will assess the extent to which they consider themselves to have excess qualifications (ability, skills, knowledge, and experience) requirements. Used in their current job. The researcher includes several examples of question items used to measure POQ, namely "My job requires a lower education than my current education." In this study, Cronbach's Alpha achieved a score of 0.85 (Kim, Park, Shon \& Lim, 2019). An example of another measurement item is "I have a higher ability than the required job requirements," with a Cronbach's Alpha score of 0.88 (Luksyte, Spitzmueller, \& Maynard, 2011). A higher score indicates a higher perceived level of overqualification than a lower score.

Job Boredom - KTP. Researchers measure KTP using a 6-item measurement scale adopted from the Dutch Boredom scale developed by Reijseger, Schaufeli, Peeters, Taris, van Beek, \& Ouweneel (2013), which is validated and has been used in previous studies (Kim, Park, Shon \& Lim, 2019; Harju, Hakanen, \& Schaufeli, 2014). The researcher used a 5-point Likert scale (point 1 , which means strongly disagree with pointing five, which means strongly agree), respondents were asked to rate the extent to which they felt bored with their current job some time ago. The researcher also includes several examples of question items used to measure KTP, namely "I feel bored with my job," with a Cronbach's Alpha score reaching 0.85 (Kim, Park, Shon \& Lim, 2019).

Counterproductive Behavior - PKP. Researchers measure PKP using a 19-item measurement scale adopted from the Workplace Deviance measurement scale developed by Bennett and Robinson (2000), validated, and used in previous research (Kim, Park, Shon \& Lim, 2019). The study used a 5-point Likert scale (point 1 , which means strongly disagree with pointing five, which means strongly agree), respondents were asked to rate the extent to which they have been involved in PKP during the last few moments. The researcher included a sample of question items such as "Saying something hurts someone at work" with a Cronbach's Alpha score of 0.93 (Kim, Park, Shon \& Lim, 2019).

\section{Procedure}

Researchers collected research data in an online format using standard survey software. Respondents were recruited through various communication channels such as email and WhatsApp based on the provisions of the snowballing technique. Researchers start by contacting a network of colleagues, friends, and acquaintances, and then from that network can contact their colleagues, friends, and acquaintances to participate in the study. To avoid bias in the study results, the researcher included several screening questions to determine whether a respondent was eligible or not eligible to be used in the data testing process.

This study uses a validity test to ensure that the study's measurement scale follows the specified conceptual, operational, and reliability definitions (Hair, Hult, Ringle, \& Sarstedt, 2014). The validity tests used in this study are face validity and content validity (Maksum, Handoko, \& Fikriah, 2020). Face validity aims to adapt the research instrument to the current research context by conducting discussions with experts (Maksum \& Fikriah, 2020). While in the content validity procedure, the researcher adjusts the overall content, definition, and 
research construct by reading and matching the existing literature (Hair, Hult, Ringle, \& Sarstedt, 2014).

The researcher also added validity tests such as convergent and discriminant validity as the outer model tests. Neuman (2016) states that convergent validity is a measuring tool that uses many indicators based on the logic that each indicator involved in a particular construct can have exciting movements and clusters in one place. Convergent constructs can be valid when the expected value of the factor load reaches a score of 0.4 to 0.7 and above (Hair, Hult, Ringle, \& Sarstedt, 2014). Meanwhile, discriminant validity relates to the principle that different construct measures should not be highly correlated. The discriminant validity test was assessed based on the cross-loading measurement with each construct. The cross-loading value shows the correlation between each construct and indicators from other block constructs. A construct has discriminant validity of the construct indicator has the highest loading value in its construct group (Hair, Hult, Ringle, \& Sarstedt, 2014). The following evaluation compares the AVE root value for each construct with the correlation between the construct and other constructs in the model. The construct will be said to meet discriminant validity when the value of the square root of the AVE construct is greater than the value of the most significant correlation between the construct and other constructs. Another test conducted by researchers is the reliability test. Neuman (2016) states that reliability is the reliability or consistency of an attribute measurement. The reference was used to see the adequacy of reliability using Cronbach's alpha values ranging from 0.60 to 0.70 or higher (Hair, Hult, Ringle, \& Sarstedt, 2014).

Furthermore, testing the structural model (inner model) as a Hypothesis Test. Researchers do structural model or hypothesis testing to observe how a construct can relate to each other based on existing theories. In this study, the data analysis method used was structural equation modeling-partial least squares (SEM-PLS) using SmartPLS software. The advantage of using SEM-PLS lies in its reliability for estimating the nature of non-linear relationships compared to other test methods, which are only limited to linear relationships. The reference used by the researcher is the assessment of the path coefficient $(\beta)$ and $p$-value, the coefficient of determination for each path (Hair, Hult, Ringle, \& Sarstedt, 2014). Positive path coefficient values indicate that exogenous variables are positively related to endogenous variables, while for negative coefficient values, exogenous variables are negatively related to endogenous variables. The hypothesis in this study is said to be supported if the $\mathrm{p}$-value $<0.01$ (significant at the $1 \%$ level), p-value $<0.05$ (significant at the $5 \%$ level), and $\mathrm{p}$-value $<0.1$ (significant at the $10 \%$ level).

The purpose of data analysis using the PLS technique is to examine three research latent variables (e.g., perception of overqualification, job boredom, and counter social behavior). The researcher also includes and examines the mediating role of KTP, which is based on the concept developed by Baron \& Kenny (1986), which discusses the mechanism of testing mediating and moderating variables. The initial testing stage directly tests the independent variable (POQ) against the dependent variable (PKP). Second, testing is done by testing the independent variable (POQ) against the mediator variable (KTP). Third, directly test the mediator variable (KTP) on the dependent variable (PKP). In the last stage, the researcher tested the independent variable (POQ) and the mediator variable (KTP) simultaneously on the independent variable (PKP). 


\section{Result}

The study used primary data collected using a questionnaire through a survey method directly to the field. The questionnaire used by the researcher was developed and validated by the previous researchers. The original questionnaire consisted of question items and was in English and translated into Indonesian to suit the research context in Indonesia. In addition, questionnaires were distributed to several Islamic Universities in Indonesia. By distributing questionnaires, it is possible for researchers to obtain a more significant amount of data and requires a shorter time and relatively lower costs (Maksum, Handoko, \& Fikriah, 2020). The results of the detailed data distribution can be referred to in the distribution table of the research questionnaire.

Table 1. Distribution of Questionnaire Research

\begin{tabular}{ccc}
\hline Gender & & Percentage \\
\hline Male & 42 & $39.6 \%$ \\
Female & 64 & $60.4 \%$ \\
Total & 106 & $100 \%$ \\
\hline Level of education & \\
\hline Strata 1 (bachelor) & 9 & Percentage \\
Strata 2 (Master) & 93 & $8.5 \%$ \\
Strata 3 (Doctor) & 4 & $3.8 \%$ \\
Total & 106 & $100 \%$ \\
\hline Lecture & 12 & $100 \%$ \\
\hline Type of work & & \\
\hline Total & 94 & Percentage \\
\hline
\end{tabular}

Source: Processed primary data, 2021

Researchers use validity and reliability tests to test whether the research instrument can measure as good as the instrument you want to study (Cooper \& Schindler, 2014). Researchers use face validity and content validity to test the suitability of research instruments to the current research context and adjust the overall content, definitions, and research constructs. Furthermore, the researcher also uses convergent validity and discriminant validity. The results of the convergence test of this study refer to the cross-loading. For example, suppose the research items are grouped on the same variable and have a factor loading value greater than 0.70 and significant at the $1 \%$. In that case, practically, the measurement item meets the 
criteria for convergent validity. Table 2. describes the results of the concurrent validity test in detail.

Table 2. Convergent Validity Test

\begin{tabular}{|c|c|}
\hline Convergent Validity & Factor Loading \\
\hline \multicolumn{2}{|c|}{ KTP (Job Boredom) } \\
\hline KTP3 & 0.793 \\
\hline KTP5 & 0.835 \\
\hline KTP6 & 0.729 \\
\hline \multicolumn{2}{|c|}{ PKP (Counterproductive Work Behaviour) } \\
\hline PKP5 & 0.750 \\
\hline PKP6 & 0.755 \\
\hline PKP13 & 0.789 \\
\hline PKPI4 & 0.770 \\
\hline PKP16 & 0.722 \\
\hline PKPI7 & 0.746 \\
\hline \multicolumn{2}{|c|}{ POQ (Perception of Overqualification) } \\
\hline POQ1 & 0.805 \\
\hline POQ2 & 0.800 \\
\hline POQ5 & 0.799 \\
\hline POQ6 & 0.766 \\
\hline POQ7 & 0.709 \\
\hline POQ8 & 0.732 \\
\hline
\end{tabular}

Source: Processed primary data, 2021

The test results of the concurrent validity test show that only a few question items can be declared valid and meet the criteria for testing the convergent validity. For example, in the test of the KTP construct, there are only three of the six measurement items that meet the requirements of the concurrent validity test, namely KTP3: 0.739; ID card5: 0.835; ID card6: 0.729. While in the PKP construct, only six out of eighteen measurement items meet the convergent validity test requirements, namely PKP5: 0.750; PKP6: 0.755; PKP13: 0.789; PKP14: 0.770; PKP16: 0.722; PKP17: 0.746. Furthermore, for testing the POQ construct, the researcher only obtained six of the nine measurement items that met the requirements in the concurrent validity test, namely POQ1: 0.805; POQ2: 0.800; POQ5: 0.799; POQ6: 0.766; POQ7: 0.709; POQ8: 0.732. Therefore, researchers can delete and not include them in further testing for measurement items that do not meet the requirements of passing the convergent validity test. 
Furthermore, the researcher also conducted a discriminant validity test in this study. The discriminant validity test was assessed to compare the Average Variance Extracted (AVE) and Cross Loading on each research variable. The purpose of testing discriminant validity is to confirm the correlation between research variables in the research model. The research model can be valid if the AVE score for each variable is equal to or above 0.5 and the cross-loading score is > 0.70 (Hair, Hult, Ringle, \& Sarstedt, 2014). The results of discriminant validity testing in this study indicate no correlation problem in each research variable because all variables achieve the required minimum AVE score $>0.5$ and cross-loading score $>0.7$. The overall discriminant validity test results can be referred to in table 3.

Table 3. Diskriminant Validity Test

\begin{tabular}{|c|c|c|c|}
\hline Variable & Cross Loading & $\begin{array}{l}\text { Average Variance } \\
\text { Extracted (AVE) }\end{array}$ & Information \\
\hline \multirow{3}{*}{ KTP } & KTP3 0.739 & \multirow{3}{*}{0.592} & \multirow{3}{*}{ Valid } \\
\hline & KTP5 0.835 & & \\
\hline & KTP6 0.729 & & \\
\hline \multirow{6}{*}{ PKP } & PKP5 0.750 & \multirow{6}{*}{0.571} & \multirow{6}{*}{ Valid } \\
\hline & PKP6 0.755 & & \\
\hline & PKP13 0.789 & & \\
\hline & PKP14 0.770 & & \\
\hline & PKP16 0.722 & & \\
\hline & PKPl7 0.746 & & \\
\hline \multirow{6}{*}{ POQ } & POQ1 0.805 & \multirow{6}{*}{0.592} & \multirow{6}{*}{ Valid } \\
\hline & POQ2 0.800 & & \\
\hline & POQ5 0.799 & & \\
\hline & POQ6 0.766 & & \\
\hline & POQ7 0.709 & & \\
\hline & POQ8 0.732 & & \\
\hline
\end{tabular}

Source: Processed primary data, 2021

Table 3. This data shows that all variables in this study have met the criteria for the discriminant validity test, which is based on the AVE score that reaches a score of $>0.5$. In table 3 , the KTP variable gets a score of 0.592 , PKP gets a score of 0.571 , and the POQ variable gets a score of 0.592 . With the test results, it can be concluded that each variable used in this study has met the discriminant test. As for the cross-loading score, only a few question items meet the required score to meet the discriminant validity test. The KTP variable only has three question items that meet the minimum score, namely KTP3: 0.739; ID card5: 0.835; ID card6: 0.729. In the PKP variable, only six question items meet the minimum cross-loading score, 
namely PKP5: 0.750; PKP6: 0.755; PKP13: 0.789; PKP14: 0.770; PKP16: 0.722; PKPl7: 0.746. Furthermore, in the POQ variable, there are only six question items that have met the crossloading requirements, namely POQ1: 0.805; POQ2: 0.800; POQ5: 0.799; POQ6: 0.766; POQ7: 0.709; POQ8: 0.732. The detailed results of the cross-loading test can be referred to in table 4 .

Table 4. Cross-Loading Result

\begin{tabular}{cccc}
\hline Variable & KTP & PKP & POQ \\
KTP3 & $(0,739)$ & 0,460 & 0,283 \\
KTP5 & $(0,835)$ & 0,529 & 0,374 \\
KTP6 & $(0,729)$ & 0,406 & 0,374 \\
PKP5 & 0,545 & $\mathbf{( 0 , 7 5 0 )}$ & 0,368 \\
PKP6 & 0,412 & $(0,755)$ & 0,440 \\
PKP13 & 0,414 & $(0,789)$ & 0,310 \\
PKP14 & 0,429 & $(0,770)$ & 0,284 \\
PKP16 & 0,458 & $(0,722)$ & 0,260 \\
PKP17 & 0,470 & $(0,746)$ & 0,388 \\
POQ1 & 0,301 & 0,420 & $(0,805)$ \\
POQ2 & 0,309 & 0,318 & $(0,800)$ \\
POQ5 & 0,284 & 0,302 & $(0,799)$ \\
POQ6 & 0,472 & 0,326 & $(0,766)$ \\
POQ7 & 0,284 & 0,266 & $(0,709)$ \\
POQ8 & 0,370 & 0,433 & $\mathbf{( 0 , 7 3 2 )}$ \\
\hline Fee & &
\end{tabular}

Source: Processed primary data, 2021

In the next stage, the researcher conducted a reliability test to test whether the research variables used in this study had met the reliability requirements. The research variable can be reliable if it refers to the Cronbach's Alpha value greater than or equal to 0.6 and the Composite Reliability score greater than or equal to 0.7 (Hair, Hult, Ringle, \& Sarstedt, 2014). Hair, Hult, Ringle, \& Sarstedt (2014) state that the coefficient value resulting from Cronbach's Alpha testing ranges from 0.5 , indicating that the reliability of a construct is in the poor category but can still be used at the next level of analysis. Meanwhile, for the test score ranging from 0.6 to 0.7 , it is included in the reasonably good category, while for a score of 0.8 or more, it can be categorized as very good. The detailed reliability test results can be referred to in table 5 . regarding the reliability test. 
Table 5. Reliability Test

\begin{tabular}{cccc}
\hline Variable & Cronbach's Alpha & $\begin{array}{c}\text { Composite } \\
\text { Reliability }\end{array}$ & Information \\
\hline KTP & 0.653 & 0.812 & Reliable \\
KPK & 0.850 & 0.889 & Reliable \\
POQ & 0.862 & 0.897 & Reliable
\end{tabular}

Source: Processed primary data, 2021

Referring to table 5. all the variables involved in this study are declared reliable, following the achievement of the minimum score requirement of Cronbach's Alpha which ranges from a minimum of 0.6 or more and a Composite Reliability score of 0.7 or more (Hair, Hult, Ringle, $\&$ Sarstedt, 2014 ). For example, the KTP variable obtained a Cronbach's Alpha score of 0.653 and Composite Reliability of 0.812. In contrast, the KPK variable obtained a score of 0.850 and 0.889 , and the POQ variable obtained a score of 0.862 and 0.897 . thus, each measurement item can consistently and reliably measure each research variable.

The researcher conducted the Inner Model test to test the research hypothesis in the next stage. Researchers conduct testing of structural models or hypotheses to observe and confirm how a research construct can relate to each other based on existing theories. Researchers refer to the assessment of the path coefficient $(\beta)$ and $p$-value and the value of the coefficient of determination (Hair, Hult, Ringle, \& Sarstedt, 2014). If the path value is positive, the exogenous variable is positively related to the endogenous variable and vice versa. Researchers set the conditions for the support of the research hypothesis if, $\mathrm{p}$-value $<0.01$ (significant at the $1 \%$ level), p-value $<0.05$ (significant at the $5 \%$ level), and p-value $<0.1$ (significant at the $10 \%$ level). The results of the Inner Model testing in this study can be referred to in table 6 .

Table 6. Inner Model Test

\begin{tabular}{cc}
\hline Variable & $R$-Square \\
\hline KTP & 0.201 \\
PKP & 0.412 \\
\hline \multicolumn{2}{l}{ Source: Processed primary data, 2021 }
\end{tabular}

Referring to the Inner Model test results presented in table 6, the R-Square value for the KTP variable gets a score of 0.021 , which can be interpreted that the magnitude of the influence of the POQ variable on the KTP variable is $20.1 \%$. In comparison, the remaining $79.9 \%$ is explained by other variables not involved in this study. While the R-Square value for the PKP variable reaches 0.412 , which means that the magnitude of the influence of the POQ variable on the KPK variable is $41.2 \%$, the remaining $58.8 \%$ is influenced by other factors not included in this study. 
After testing the Inner Model, the researcher tested the research hypothesis by referring to the mechanism for testing the effect of moderation-mediation developed by Baron \& Kenny (1986).

Table 7. Hypothesis Testing on Specific Direct Effect Total Effects Mean, STDEV, T-Values, P-Values

\begin{tabular}{cccccc}
\hline Hypothesis & $\begin{array}{c}\text { Original } \\
\text { Sample (O) }\end{array}$ & $\begin{array}{c}\text { Sample } \\
\text { Mean (M) }\end{array}$ & $\begin{array}{c}\text { Standard } \\
\text { Deviation } \\
(\text { STDEV) }\end{array}$ & $\begin{array}{c}\text { T-Statistics } \\
(\text { IO/STDEVI) }\end{array}$ & P-Value \\
\hline KTP $\rightarrow$ PKP & 0.504 & 0.501 & 0.082 & 6.170 & 0.000 \\
POQ $\rightarrow$ KTP & 0.448 & 0.464 & 0.083 & 5.385 & 0.000 \\
POQ $\rightarrow$ PKP & 0.457 & 0.468 & 0.094 & 4.862 & 0.000 \\
\hline
\end{tabular}

Source: Processed primary data, 2021

Based on the Inner Model table and the hypothesis test table, it can be concluded that there is a positive effect of POQ on PKP. The effect can be referred to as the R-Square value of 0.412 , P-Value of 0.000 , and the value of Sig. of 0.001 . The hypothesis test results show that POQ has a positive and significant effect on PKP based on the R-Square value of 0.412, which means that the POQ variable of $41.2 \%$ can explain the variance in the PKP variable. The remaining $58.8 \%$ can be explained by other variables not involved in this research. Therefore, by referring to this value, it can be concluded that hypothesis 1 has been supported.

Table 8. Hypothesis Testing on Specific Indirect Effect Total Effects Mean, STDEV, T-Values, P-Values

\begin{tabular}{lccccc}
\hline Hypothesis & $\begin{array}{c}\text { Original } \\
\text { Sample } \\
(\mathrm{O})\end{array}$ & $\begin{array}{c}\text { Sample } \\
\text { Mean (M) }\end{array}$ & $\begin{array}{c}\text { Standard } \\
\text { Deviation } \\
(\mathrm{STDEV})\end{array}$ & $\begin{array}{c}\text { T-Statistics } \\
(\mathrm{IO} / \text { STDEVI })\end{array}$ & P-Value \\
\hline POQ $\rightarrow$ KTP $\rightarrow$ PKP & 0.226 & 0.234 & 0.063 & 3.605 & 0.000 \\
\hline
\end{tabular}

Source: Processed primary data, 2021

In testing the mediating effect, the researcher assumes that the output of the significance test parameter refers to the Total Effect table, not the coefficient table. The reason is that the mediating effect considers testing the influence between independent variables on the dependent variable directly and has to consider testing through mediating variables (indirect effect) (Baron \& Kenny, 1986). Thus, Total Effect is better if used to confirm predicting direct and indirect effects between research variables. Based on the Total Effects table, the TStatistic value gets a score greater than 1.96, which means that the KTP variable fully mediates the indirect effect of POQ on PKP. With a T-Statistic value reaching 3,605 and higher than 1.96, P-Value 0.000 and Sig. of 0.001, thus hypothesis 2 has been supported. 


\section{Discussion}

\section{Direct Effects of Perceived Overqualification and Counterproductive Behavior}

Burris (1983) states that when someone works in a job that does not follow the qualifications, someone can experience frustration. Overqualification of an employee can increase the risk of counterproductive behavior aimed at assuaging feelings of wasting valuable resources (e.g., time, effort, and knowledge). The results of this study are consistent with the work frustration-aggression model from Fox \& Specter (1999), which explains that a person can respond to events that make them frustrated by engaging in counterproductive behavior. In addition, it also has an impact on a person's emotional state. When people feel that they are overqualified, they can trigger unpleasant emotional responses in their work environment, which in turn can lead to negative emotions such as excessive frustration, anger, job dissatisfaction, job hatred, and job boredom (Penney \& Spector, 2008; Liu, Luksyte, Zhou, Shi, \& Wang, 2014). The consequence of the emergence of various negative emotions is an employee's involvement in counterproductive behavior.

The researcher integrates the theory of person-job fit to explain the impact when someone has excessive qualifications in doing their job. Researchers argue that the perception of overqualification can positively affect counterproductive behavior (Liu, Luksyte, Zhou, Shi, \& Wang, 2014). This finding is consistent with research conducted by Kim, Park, Shon \& Lim (2019), which found that a worker who has a perception that they have excess skills, education, and experience in their work, can trigger negative emotions such as feelings of suffering, low well-being. Psychologically, low organizational commitment and ultimately engage in counterproductive behavior. Someone who has higher qualifications than the job requirements can feel angry with their organization for not offering challenges in their work. The presence of negative emotions in the form of anger can then cause an affective reaction to the work situation, and in the end, counterproductive behavior occurs. Based on this logic, the researcher can conclude a positive and significant effect of POQ on PKP.

\section{Indirect Effect of Perceived Overqualification on Counterproductive Behavior Through Boredom on Work}

Based on the theory of person-job fit, P- $\mathrm{J}$ fit relates to the suitability or compatibility between a person and their job (Liu, Luksyte, Zhou, Shi, \& Wang, 2014). At the same time, POQ is the perception of a person's skills, education, and experience mismatch with their job needs (Penney \& Spector, 2008). According to the literature, poor P-J fit can be associated with low job satisfaction, high turnover intention, poor overall performance, job boredom, and counterproductive behavior. In addition, workers with poor job compatibility can lead to negative experiences such as job boredom (Kim, Park, Shon \& Lim, 2019). When feeling bored with work arises, it triggers a person's perception that their abilities cannot be adequately used in their work.

Consistent with this statement, research from Luksyte, Spitzmueller, \& Maynard (2011) found a positive and significant influence between perceptions of overqualification, job boredom, and the output, namely counterproductive behavior. In addition, the boredom that arises is also caused by a lack of workload, lack of job challenges, and lack of utilization of a worker's skills in his work. When a person feels that they are not appropriately used in their work environment, they can feel frustrated and depressed. Feelings of frustration and pressure 
that arise from a worker's perception can be referred to as negative emotions that lead to boredom with their work and ultimately counterproductive behavior (Kim, Park, Shon \& Lim, 2019). With this logic of thinking, there is an evident influence of KTP as a mediator between POQ and PKP.

\section{Conclusion}

This research contributes to various literature related to the critical role of job occupations that explain the path of the influence of overqualified behavior on counterproductive behavior, and the $\mathrm{P}-\mathrm{J}$ fit literature as a theoretical basis for explaining the phenomenon that causes a person to engage in counterproductive behavior. This study shows that job boredom fully mediates the effect of perceived overqualification on counterproductive behavior. The study results have implications for practitioners, that a high mismatch between skills, education, and experience with job requirements can harm the organization. Following the P-J fit theory, a high mismatch between worker qualifications and job requirements can trigger counterproductive behavior. Thus, practitioners are expected to avoid a mismatch of abilities and job requirements for their employees to reduce the risk of counterproductive behavior. At the same time, the implication for practitioners is that this research contributes to the enrichment of literature that discusses the critical role of job boredom as a mediating variable for the path of the influence of perceived overqualification on counterproductive behavior.

However, the current research still has limitations, so future research needs to improve. The first drawback is limited research samples that only cover Islamic universities. It is hoped that future research will cover a more comprehensive sample involving universities in general to produce mixed research results. Second, the researcher only uses the job boredom mediating role mechanism (KTP). It is hoped that future research can consider the moderating role of organizational citizenship behavior (PKO) to confirm its effect on counterproductive behavior. Third, the current study only uses research samples in the education sector, which have characteristics of low job demands, so they are less relevant to measure the effect of perceived overqualification (POQ) on counterproductive behavior (PKP). Future research is expected to consider using research samples in the private sector, which requires higher performance demands than the education sector, so the impact of perceived overqualification can be better investigated. 


\section{References}

Baron, R. M., \& Kenny, D. A. (1986). The moderator-mediator variable distinction in social psychological research: Conceptual, strategic, and statistical considerations. Journal of personality and social psychology, 51(6), 1173.

Bennett, R. J., \& Robinson, S. L. (2000). Development of a measure of workplace deviance. Journal of applied psychology, 85(3), 349.

Bruursema, K., Kessler, S. R., \& Spector, P. E. (2011). Bored employees misbehaving: The relationship between boredom and counterproductive work behavior. Work \& Stress, 25(2), 93-107.

Burris, B. H. (1983). The human effects of underemployment. Social Problems, 31(1), 96-110.

Cooper, D.R., dan Schindler, P.S. (2014). Business Research Methods, 12ed. New York: Mcgraw-Hill.

Deng, H., Guan, Y., Wu, C. H., Erdogan, B., Bauer, T., \& Yao, X. (2018). A relational model of perceived overqualification: The moderating role of interpersonal influence on social acceptance. Journal of Management, 44(8), 3288-3310.

Erdogan, B., Bauer, T. N., Peiró, J. M., \& Truxillo, D. M. (2011). Overqualified employees: Making the best of a potentially harmful situation for individuals and organizations. Industrial and organizational psychology, 4(2), 215-232.

Fox, S., \& Spector, P. E. (1999). A model of work frustration-aggression. Journal of organizational behavior, 20(6), 915-931.

Gibson, D. E., \& Callister, R. R. (2010). Anger in organizations: Review and integration. Journal of Management, 36(1), 66-93.

Green, F., \& Zhu, Y. (2010). Overqualification, job dissatisfaction, and increasing dispersion in the returns to graduate education. Oxford economic papers, 62(4), 740-763.

Hair, J.F., Hult, G.T.M., Ringle, C.M., dan Sarstedt, M. (2014). A Primer on Partial Least Squares Structural Equation Modelling (PLS-SEM). Thousand Oaks, CA: Sage.

Harari, M. B., Manapragada, A., \& Viswesvaran, C. (2017). Who thinks they are big fish in a small pond, and why does it matter? A meta-analysis of perceived overqualification. Journal of Vocational Behavior, 102, 28-47.

Harju, L., Hakanen, J. J., \& Schaufeli, W. B. (2014). Job boredom and its correlates in 87 Finnish organizations. Journal of occupational and environmental medicine, 56(9), 911-918.

Holtz, B. C., \& Harold, C. M. (2013). Effects of leadership consideration and structure on employee perceptions of justice and counterproductive work behavior. Journal of Organizational Behavior, 34(4), 492-519.

Kim, J., Park, J., Sohn, Y. W., \& Lim, J. I. (2019). Testing a moderated mediation model, perceived overqualification, boredom, and extra-role behaviors. Journal of Career Development, 0894845319853879. 
Kristof-Brown, A., \& Guay, R. P. (2011). Person-environment fit. In APA handbook of industrial and organizational psychology, Vol 3: Maintaining, expanding, and contracting the organization. (pp. 3-50). American Psychological Association.

Liu, S., \& Wang, M. (2012). Perceived overqualification: A review and recommendations for research and practice. The role of the economic crisis on occupational stress and wellbeing.

Liu, S., Luksyte, A., Zhou, L., Shi, J., \& Wang, M. (2014). Overqualification and counterproductive work behaviors: Examining a moderated mediation model. Journal of Organizational Behavior, 36(2), 250-271.

Luksyte, A., Spitzmueller, C., \& Maynard, D. C. (2011). Why do overqualified incumbents deviate? Examining multiple mediators. Journal of occupational health psychology, 16(3), 279.

Maksum, I., \& Fikriah, N. L. (2020). Kepemimpinan islami dan etika kerja islami: Pengaruhnya terhadap kinerja karyawan. Li Falah: Jurnal Studi Ekonomi dan Bisnis Islam, 3(1), 90-110.

Maksum, I., Handoko, T. H., \& Fikriah, N. L. (2020). Group cohesiveness on performance: mediating effect of collective organization citizenship behavior. Jurnal Manajemen, 24(03), 443-459.

Maynard, D. C., \& Parfyonova, N. M. (2013). Perceived overqualification and withdrawal behaviors: Examining the roles of job attitudes and work values. Journal of occupational and organizational psychology, 86(3), 435-455.

Maynard, D. C., Joseph, T. A., \& Maynard, A. M. (2006). Underemployment, job attitudes, and turnover intentions. Journal of Organizational Behavior: The International Journal of Industrial, Occupational and Organizational Psychology and Behavior, 27(4), 509-536.

Neuman, W, L. (2016). Metodologi penelitian sosial: pendekatan kualitatif dan kuantitatif (7th ed.). Jakarta Barat: PT Indeks.

Penney, L. M., \& Spector, P. E. (2008). Emotions and counterproductive work behavior.

Reijseger, G., Schaufeli, W. B., Peeters, M. C., Taris, T. W., Van Beek, I., \& Ouweneel, E. (2013). Watching the paint dry at work: Psychometric examination of the Dutch Boredom Scale. Anxiety, Stress e Coping, 26(5), 508-525.

Shen, K., \& Kuhn, P. (2013). Do Chinese employers avoid hiring overqualified workers? Evidence from an internet job board. In Labor Market Issues in China. Emerald Group Publishing Limited.

van Hooff, M. L., \& van Hooft, E. A. (2014). Boredom at work: Proximal and distal consequences of affective work-related boredom. Journal of occupational health psychology, 19(3), 348.

Watt, J. D., \& Hargis, M. B. (2010). Boredom proneness: Its relationship with subjective underemployment, perceived organizational support, and job performance. Journal of business and psychology, 25(1), 163-174. 